(p. 77), will be found worthy of careful consideration.

To those who have been so long hoping that some day the importance of science in connection with industry would be recognised by the State, the Government scheme for industrial research is a source of satisfaction. The department now established has made a good beginning in affording assistance to many workers from the fund of one million granted by the Government and in encouraging the formation of research associations among manufacturers. Many of these are already in operation and are enumerated, with the names of their officers, in the comprehensive volume under notice.

\section{THE BIRDS OF COLOMBIA.}

Bulletin of the American Museum of Natural History. Vol. xxxvi., I917. The Distribution of Bird-Life in Colombia: A Contribution to a Biological Survey of South America. By Dr. Frank M. Chapman. Pp. $x+729+x l i$ plates. (New York: The American Museum of Natural History, I9r7.)

D. CHAPMAN'S "Report on the Distribution of Bird-Life in Colombia" ranks amongst the most important contributions ever made to the knowledge of the ornis of the Neotropical Region, the avifauna of which stands unrivalled both in the wealth and variety of its feathered forms and in the number of its peculiar family and generic types. Colombia, thanks to Dr. Chapman's investigations, is now known to be the richest portion of this remarkable area so far as birdlife is concerned. That this should be so is due, no doubt, to the varied physiographical features to be found in that equatorial republic, for these range from tropical pasture-lands and forests at low, or comparatively low, levels to regions of perpetual snow in the Cordilleras, and include the uppermost tributaries of the Orinoco and some of those of the Amazon.

In the year I9Io the American Museum of Natural History organised and commenced a series of expeditions for the systematic exploration of the bird-life of the republic. These extended over five years, and were carried out under the direction of Dr. Chapman, who himself took part in them in rglo and again in 1913. As the result of these systematic and well-organised explorations, I5,775 specimens, representing $\mathrm{I}_{2} 8_{5}$ forms (species and subspecies), were obtained. Hence the report is based not only upon scientifically collected data, but also upon intimate personal knowledge of the country and its birds on the part of its author - a combination which has rendered the work of inestimable value.

As the result of his studies on this ideal system, Dr. Chapman recognises the following vertical life-zones: A tropical, which ranges up to $4500-6000 \mathrm{ft}$; ; a sub-tropical, from $4500-6000 \mathrm{ft}$. to $9000-9500 \mathrm{ft}$; ; a temperate, from $9000-0500 \mathrm{ft}$. to II, $000-\mathrm{I}_{3}, \mathrm{OOO} \mathrm{ft}$; a paramo (high plateau), No. 2598 , VOL. $\left.\mathrm{IO}_{3}\right]$ from Ix,O00-I3,000 $\mathrm{ft}$. to the snow-line at I 5, $000 \mathrm{ft}$. These zones he again subdivides into faunal areas, so that the distribution of bird-life in Colombia is worked in remarkable detail. The author tells us that the uniformity of life increases with altitude, and that the distinctness of the various animals and plants of these several zones was a constant source of surprise and joy to him.

It is quite impossible here to enter into details of the various distributional problems unfolded by the author, but the portions of the work devoted to them are the most interesting and valuable to be found in this great work.

The systematic portion of the report treats in detail of the distribution, plumage, haunts, habits, etc., of the 1285 forms of bird-life which constitute the ornis of Colombia. Of these, twenty-two species and II 5 subspecies are new to science. It is much to be regretted that Dr. Chapman has not included in his report the birds, some 400 in number, which had previously been recorded, but did not come under the notice of himself or his explorers. If this had been done it would have rendered his volume a complete record of all that is known to date of the avifauna of Colombia.

The volume is enriched by a series of reproductions of photographs of scenery depicting the various life-zones, and of useful maps and charts illustrating the distribution of species, forests, etc. It is further embellished by four coloured plates, devoted to the newly discovered birds, by the well-known zoological artist, Louis Agassiz Fuertes, who accompanied Dr. Chapman on two of his expeditions.

The author is to be heartily congratulated on the completion of his admirable work and on the masterly manner in which he has presented its results. Congratulations are also due to that enlightened institution, the American Museum of Natural History, which made this grand undertaking possible.

W. E. C.

\section{OUR BOOKSHELF.}

Practical Physiological Chemistry. A Book Designed for Use in Courses in Practical Physiological Chemistry in Schools of Medicine and of Science. By Prof. Philip B. Hawk. Sixth edition, revised and enlarged. Pp. xiv $+66 \mathrm{I}+\mathrm{vi}$ plates. (London: J. and A. Churchill, I919.) Price $2 \mathrm{~s} s$. net.

THrs book, written by one of the best known of American physiological chemists, first appeared in 1907. Its success is evident from the fact that it is now in its sixth edition, and is due to the clearness and completeness of the practical instructions with which it is packed. It does not pretend to be a complete work of reference, but though designed for the use of students, it is far too exhaustive for the ordinary student of medicine, who in the few years of his curriculum has to learn so many other subjects, and it is difficult to imagine that the American student can devote 